\title{
Present treatment of breast cancer
}

\author{
J. L. GROGONO \\ M.B., F.R.C.S. \\ The London Hospital, London, E. 1
}

\section{Summary}

Fifty surgeons and ten radiotherapists were asked to advise treatment in various hypothetical cases of breast cancer. The thirty-nine replies are analysed, and show very wide variation, both in the extent of direct surgical attack, and in the various adjunctive measures. The results of longterm controlled trials may eventually produce more uniform patterns of treatment.

\section{Introduction}

At present, there is no general agreement on a policy for the treatment of breast cancer. This is true for almost all stages and presentations of the disease, but particularly when it is apparently still localized, and also when local recurrence occurs some time after primary treatment. This survey was undertaken to determine current methods of treatment and their degree of variation, when different surgeons and radiotherapists are presented with the same hypothetical problems.

\section{Method}

A circular was sent to fifty general surgeons and ten radiotherapists on the staffs of the following hospitals: The London Hospital, St George's Hospital, The Royal Marsden Hospital, and twelve hospitals in the North-East Metropolitan Region. They were asked to give, in their opinion, the optimum initial treatment in each of the following cases:

(1) A fit, premenopausal, 40-year-old woman, with three children aged $10-15$, has recently noticed a small swelling in the upper outer quadrant of one breast, 2 in. from the nipple, unattached to skin or deep structures, and with no significantly palpable lymph nodes, or other evidence of spread (Stage I or $T_{I} N_{0}$ $\mathbf{M}_{0}$ ). Histology shows it to be a moderately differentiated invasive carcinoma of breast.

(2) An exactly similar patient to (1), except that the swelling is in the upper inner quadrant, 2 in. from the nipple.

(3) An exactly similar patient to (1), except histology shows highly anaplastic carcinoma of breast.

(4) Suppose the patient described in (1), had had a classical radical mastectomy as the only original treatment, and presents 3 years later with two small skin nodules in the mastectomy scar which are strongly suggestive of carcinoma, and no other evidence of spread.

(5) Suppose the patient described in (1), had had a classical radical mastectomy as the only original treatment, and presents 3 years later with a small, hard, fixed swelling in the ipsilateral axilla, which is strongly suggestive of carcinoma.

\section{Results}

Thirty-nine replies were received. Answers to the first three questions, which concern apparently localized tumours, are summarized in Tables 1 and 2.

Table 1 shows the types of breast operation. The 'modified radical mastectomy' group includes all answers which indicated complete axillary clearance, with preservation of pectoralis major. Answers which indicated 'low axillary clearance' or 'excision of accessible axillary nodes' are included under 'extended simple mastectomy'.

Table 2 shows the recommendations for radiotherapy and oophorectomy, in relation to the type of breast operation. Details of radiotherapy were given in some answers, and included, for example, irradiation of the internal mammary nodes in all cases where radiotherapy was given for an inner quadrant tumour. In some answers, radiotherapy was recommended only if the axillary nodes were found to be involved; this occurred in seven answers to Question 1 and three answers to Question 3.

Table 3 summarizes the answers to Questions 4 and 5, concerning 'scar' and 'axillary' recurrence. The various adjunctive treatments are shown in relation to the type of surgery to the recurrence. In one answer, hypophysectomy was advised only if indicated by the Bulbrook discriminant factor. 
TABLE 1

Type of breast operation in early cases (Questions 1-3)

\begin{tabular}{lcccc}
\hline \multirow{2}{*}{ Operation } & \multicolumn{2}{c}{ Outer half tumour } & & Inner half tumour \\
\cline { 2 - 3 } \cline { 5 - 5 } & $\begin{array}{c}\text { Differentiated } \\
\text { (Question 1) }\end{array}$ & $\begin{array}{c}\text { Anaplastic } \\
\text { (Question 3) }\end{array}$ & & $\begin{array}{c}\text { Differentiated } \\
\text { (Question 2) }\end{array}$ \\
\hline Classical radical mastectomy & 20 & 16 & & 7 \\
Modified radical mastectomy & 10 & 6 & \\
Extended simple mastectomy & 3 & 2 & 1 \\
Simple mastectomy & 5 & 10 & 1 \\
Segmental mastectomy & 1 & 3 & 1 \\
Local excision of tumour & & 1 & \\
Drill biopsy & & & 1 \\
\hline
\end{tabular}

TABLE 2

Recommendations for radiotherapy and oophorectomy in relation to type of breast operation (thirty-nine answers)

\begin{tabular}{|c|c|c|c|c|c|c|c|c|c|c|c|c|}
\hline & \multicolumn{4}{|c|}{$\begin{array}{c}\text { Outer half (differentiated) } \\
\text { Question 1 }\end{array}$} & \multicolumn{4}{|c|}{$\begin{array}{l}\text { Outer half (anaplastic) } \\
\text { Question } 3\end{array}$} & \multicolumn{4}{|c|}{$\begin{array}{l}\text { Inner half } \\
\text { Question } 2\end{array}$} \\
\hline & Total & $+\mathrm{DXR}$ & $\begin{array}{c}+ \\
\text { oopho- } \\
\text { rectomy }\end{array}$ & $\begin{array}{l}+ \text { DXR } \\
\text { and } \\
\text { oopho- } \\
\text { rectomy }\end{array}$ & Total & + DXR & $\begin{array}{c}+ \\
\text { oopho- } \\
\text { rectomy }\end{array}$ & $\begin{array}{c}+ \text { DXR } \\
\text { and } \\
\text { oopho- } \\
\text { rectomy }\end{array}$ & Total & $+\mathrm{DXR}$ & $\begin{array}{c}+ \\
\text { oopho- } \\
\text { rectomy }\end{array}$ & $\begin{array}{l}\text { +DXR } \\
\text { and } \\
\text { oopho- } \\
\text { rectomy }\end{array}$ \\
\hline $\begin{array}{l}\text { Radical } \\
\text { mastectomy } \\
\text { (both types) }\end{array}$ & 30 & 8 & 5 & 5 & 22 & 4 & 3 & 12 & 10 & 4 & 2 & 3 \\
\hline $\begin{array}{l}\text { Simple } \\
\text { mastectomy } \\
\text { (including } \\
\text { extended) }\end{array}$ & 8 & 3 & & 2 & 12 & 7 & & 4 & 19 & 10 & & 6 \\
\hline Local excision & 1 & & & & 5 & 3 & & 1 & 10 & 7 & 1 & 1 \\
\hline
\end{tabular}

TABLE 3

Treatment of scar, and axillary, recurrence (thirty-nine answers)

\begin{tabular}{|c|c|c|c|c|c|c|c|c|}
\hline \multirow{2}{*}{$\begin{array}{l}\text { Surgery to } \\
\text { recurrence }\end{array}$} & \multicolumn{4}{|c|}{ Scar recurrence (Question 4) } & \multicolumn{4}{|c|}{ Axillary recurrence (Question 5) } \\
\hline & Total & $+\mathbf{D X R}$ & +oophorectomy & $\begin{array}{l}+\mathrm{DXR} \text { and } \\
\text { oophorectomy }\end{array}$ & Total & $+\mathrm{DXR}$ & +oophorectomy & $\begin{array}{c}\text { +DXR and } \\
\text { oophorectomy }\end{array}$ \\
\hline Nil, or biopsy only & 18 & 8 & $\stackrel{3}{(\mathrm{AAA})}$ & $\begin{array}{c}7 \\
\text { (A) }\end{array}$ & 28 & $\begin{array}{l}12 \\
(T)\end{array}$ & $\begin{array}{l}1 \\
\text { (A) }\end{array}$ & $\begin{array}{c}15 \\
\text { (AAT) }\end{array}$ \\
\hline Excision & $\begin{array}{l}21 \\
(\mathrm{H})\end{array}$ & 7 & $\begin{array}{c}5 \\
(\mathrm{~T})\end{array}$ & $\begin{array}{c}4 \\
\text { (A) }\end{array}$ & $\begin{array}{l}11 \\
(\mathrm{H})\end{array}$ & 2 & 2 & $\begin{array}{c}4 \\
(\mathrm{~T})\end{array}$ \\
\hline
\end{tabular}

Notes: (i) Each letter (A, H or T) indicates that in one answer in that group additional treatment was advised, as follows: $\mathbf{A}=$ Adrenalectomy; $\mathbf{H}=$ hypophysectomy; $\mathbf{T}=$ testosterone.

(ii) Two answers to Question 4 recommended wide excision with skin graft, and one answer to Question 5 recommended wide axillary clearance. 


\section{Discussion}

This survey was prompted by working with several surgeons, who use widely differing techniques when treating apparently similar cases of breast cancer. The tables show this wide variation, both in type of breast surgery and in adjunctive treatment. Other points from the tables are:

(1) The extent of recommended breast surgery is greater in the better prognosis cases, i.e. if an early tumour is outer half, differentiated, or if recurrence is limited to the scar.

(2) Adjunctive treatment, if advised, varies greatly. In early cases, radiotherapy and oophorectomy are employed, either separ- ately or together, and are recommended more when the prognosis is poor, i.e. anaplastic and inner half tumours. In recurrence, there is no obvious pattern to the wide range of recommendations, shown in Table 3. Out of seventy-eight answers to the two questions, the number of recommendations for each form of adjunctive treatment is: radiotherapy, fifty-nine; oophorectomy, forty ; adrenalectomy, eight ; testosterone, four ; hypophysectomy, two.

The wide variations reflect uncertainty in treatment. They are likely to remain, at least until more long-term results of controlled clinical trials are available. 